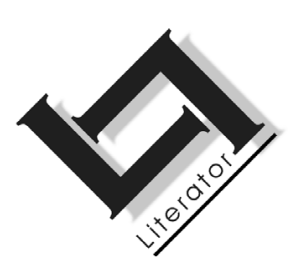

\title{
Black writers' Shona novels of the liberation war in Zimbabwe: an art that tells the truth of its day
}

\author{
D.E. Mutasa
}

Department of African Languages

University of South Africa

PRETORIA

E-mail: mutasde@unisa.ac.za

W.L. Chigidi

Department of African Languages and Culture

Midlands State University

ZIMBABWE

E-mail: chigidiwl@msu.ac.zw

\begin{abstract}
Black writers' Shona novels of the liberation war in Zimbabwe: an art that tells the truth of its day.

Over the years Shona fiction that portrays Zimbabwe's liberation war has been a subject of severe criticism because of its tendency to falsify and distort history. This article attempts to provide answers to the question of why authors of Shona war fiction tended to romanticise the war of liberation. In pursuance of this objective this article looks at circumstances and conditions that prevailed at the time that most of the Shona stories about Zimbabwe's liberation war were written. These stories were published during the first decade of Zimbabwe's independence and it is possible to look at this time and come up with a set of interdependent cultural, economic, political and ideological conditions that helped to shape writers' perspectives on the war. The article argues that the conditions of artistic freedom that interfaced with internalised fear, the euphoria and celebration, the dominant ideology of the time, as well as the situation of competition were responsible for shaping the consciousness of the war fiction writers. In this article views expressed in interviews by some of the writers of Shona war fiction are taken
\end{abstract}


into consideration. All interviews with authors referred to in the article were carried out by the researcher.

\section{Opsomming}

\section{Swart skrywers se Shona romans oor die vryheidstryd in Zimbabwe: 'n kunsvorm wat die aktualiteit van die dag weerspieël}

Deur die jare het Shonafiksie wat oor die Zimbabwiese vryheidstryd handel onder swaar kritiek deurgeloop as gevolg van die tendens om die geskiedenis te vervals en te verdraai. Hierdie artikel poog om antwoorde te verskaf op die vraag waarom dit lyk asof skrywers van Shona-oorlogsfiksie altyd poog om die vryheidstryd te verromantiseer. In die najaag van hierdie doelstelling word gekyk na die omstandighede en die toestand wat geheers het gedurende die tyd waarin die meeste Shonastories oor die vryheidstryd geskryf is. Hierdie stories is gedurende die eerste dekade na onafhanklikheid gepubliseer. Dit is dus moontlik om na hierdie tydvak te kyk en dan vorendag te kom met 'n stel interafhanklike kulturele, ekonomiese, politieke en ideologiese omstandighede wat moontlik die skrywers se indrukke van die oorlog help vorm het. Die artikel gaan van die veronderstelling uit dat die omstandighede rondom artistieke vryheid binne die raamwerk van interne vrees, die euforie en feesviering, die dominante ideologie van die tyd, sowel as die situasie van kompetisie verantwoordelik was vir die vorming van die bewustheid van die skrywers van oorlogfiksie. Die siening van sommige van sodanige skrywers, soos dit na vore gekom het gedurende persoonlike onderhoude, word deurgaans in ag geneem. Alle onderhoude waarna in hierdie artikel verwys word, is deur die skrywer self gevoer.

\section{Introduction}

The Second War of Liberation that the indigenous people of Zimbabwe waged against settler occupation and colonial rule was an event of monumental proportions that had far-reaching effects for the country, the region and perhaps the rest of the world. It affected and changed the lives of many people in many ways. Thousands of people died, hundreds were permanently maimed, others rose to fame, and many got rich while others got land that they could call their own for the first time. It was imperative that an event of this magnitude and influence should provide writers with ready-made material which they could use to write their fiction, because there is always an intrinsic relationship between literature and society. Writers of fiction often draw their material and their inspiration from happenings in their environment. The Second War of Liberation in Zimbabwe cer- 
tainly provided that kind of material and inspiration. However, the picture of the liberation war that readers see through reading Shona liberation war fiction is far from being realistic, and there are several factors that explain that. This article discusses those factors. Before doing that it is, however, essential to look at the state of things as they were before Zimbabwe's independence. This should provide a contrast and a springboard from which to launch the discussion on the situation in the post-colonial era.

\section{War actions and memories: unpublished material}

The armed struggle in Zimbabwe lasted for nearly thirteen years, yet throughout that entire period no single Shona novel depicting the liberation war was published. It was not possible for a work of art that did not reflect the general colonial settler ideology to be published and remain unbanned. Any work of fiction that talked about a war in which blacks were killing whites, even though whites were also killing blacks, was not allowed to be published.

The Rhodesian Literature Bureau, a department of government under the Ministry of Information under whose supervision the development and distribution of literature in indigenous languages took place, would never have allowed such novels to be published. Headed by Walter Krog, a former District Commissioner, the role of the Rhodesian Literature Bureau was to guide the development of literature in indigenous languages along lines acceptable to the government of the day. As Chiwome (2002:35) observes, "The resultant fiction was underdeveloped by avoiding politics, the root of the reality dealt with in fiction". By avoiding politics therefore, writers were doing what Ngugi wa Thiong'o (1981:74) calls "avoiding big issues of the day", the "social reality or certain aspects of social reality" that literature must reflect. To write about the war of liberation at this time was tantamount to writing politics. This is not to suggest that it is wrong to write politics. In colonial Zimbabwe, it depended largely on the perspective from which one wrote about the war. White authors who wrote about the war from within the dominant colonial settler ideology had their works published inside and outside the country and the books were made available in the bookshops. Such books include Peter Stiff's The rain goddess (1973), Michael Hartmann's Game for vultures (1973), and Robert Early's A time of madness (1977). The dominant colonial settler ideology is manifested in these novels by the fact that the war the blacks were waging is not seen as a war but as a rebellion (Chennels, 1995:104), and in contrast to what happens in the Shona war novels, guerrillas are depicted not 
as heroes but as uncivilised savages, murderers and terrorists. Such novels could be published because they agreed with the dominant colonial settler ideology which viewed guerrillas as senseless communist inspired killers with no moral authority on their side.

The fact that an English novel (The rain goddess) based on Zimbabwe's Second War of Liberation and written by a white person appeared as early as 1973 and the fact that many more followed throughout the time that the war was raging on, is a clear indication that the war was an event that attracted the attention of many writers, presumably both black and white. However, while a plethora of fictional works about Zimbabwe's guerrilla war written by whites in English appeared during the liberation war itself, no single Shona war novel was published before 1980. The theme of Zimbabwe's liberation war was a political one. "Unlike the pre-independence Zimbabwean novel in English whose fate was decided in Europe, the fate of the Shona novel was determined at home" (Chiwome, 2002:34) where the theme of guerrilla war was taboo. The Rhodesia Literature Bureau that received and vetted Shona manuscripts would not recommend war novels for publication. It had become "a de facto Government Censor Board which employed editors to perform the function" (Chiwome, 2002:38). Chiwome shows that there are several instances when manuscripts were rejected or doctored by the Rhodesia Literature Bureau because they dealt with sensitive issues, and he gives examples of books such as Solomon Mutswairo's Feso (1956), E.M. Zanza's Hunde Yorufu (1971) and Mordekai Hamutyinei's two manuscripts that were rejected in the mid1960s.

If the works of authors that are given above could not be published in their original form or could be banned because they expressed protest against colonial injustice Shona war novels about the liberation struggle of the 1970s had no chance of being published under the supervision of the Rhodesia Literature Bureau. Fiction that depicted the guerrillas as people with a great moral authority on their side because they believed they were fighting to create democratic space that would enable them to reclaim their land and birthright, would be judged to be subversive. Such works would not be published and the author would be in serious trouble with the police. Aaron Chiundura Moyo, one of the writers of Shona war stories, explained in an interview with the researcher that African editors at the Bureau protected black authors by removing offensive material from their manuscripts. However, what Moyo calls "protection" is actually what Chiwome (2002:37) calls "external censorship", which 
tended to frustrate artistic creativity. Censorship is to art what lynching is to justice (Gates, 1990:137). Izevbaye (1990:135) asserts

... censorship is or should be a central concern of literary criticism. It strikes at the foundation of the language and human creativity. It threatens the health of the community, undermining the bases of proper communication.

On the basis of what is known of the fate of some works by Shona writers before Zimbabwe's independence, it seems safe to argue that it was impossible to publish Shona war novels in colonial Zimbabwe. However, the fact that within the first five years of independence no less than ten Shona works depicting the Second War of Liberation in Zimbabwe were published, indicates that a new set of conditions and circumstances favoured this development. Attention can now be turned to the circumstances that prevailed in the postcolonial era that influenced Shona writers' perspectives on the liberation war.

\section{Independence and freedom}

The activity on the literary scene, the urgency and the willingness to write Shona works about the liberation war by Shona writers in the years immediately following the attainment of independence, stand in clear contrast to the inactivity and reluctance to write about the same war that characterised the liberation war years. It is clear that the attainment of independence and freedom created an enabling environment in which writers could then express the experiences of the liberation war in what Kaarsholm (2005:4) calls "a new mass of writing and publications freed from the shackles of colonial control and manipulation". Zimbabwe became independent on 18 April 1980. Independence brought with it freedom. To many Zimbabweans, freedom meant many things. However, to black Zimbabwean authors of Shona novels independence and freedom meant, among other things, the freedom to write what they felt they wanted to write without any restrictions. Freedom is a state of being able to do what you want to do without being restricted by anything or anyone. Ngugi wa Thiong'o (1981:73) has correctly observed that "whether actively involved in political struggle or not, many African writers have often found that the very subject-matter of their poems and stories has placed them on the wrong side of the ruling cliques". After Zimbabwe's independence those writers who had hitherto felt they could not write politics felt they were now free to write politics. For some of them writing politics meant writing about the Second War of Liberation and condemn colonialism. They could now do this without fear 
that subject-matter is "placing them on the wrong side of the new ruling clique". They felt that they were now free to write what they had been prohibited from writing under the watchful eye of the Rhodesia Literature Bureau. Their readers would no longer be afraid to be discovered by authorities reading a Shona book on Zimbabwean politics, because they were no longer slaves. Both literature and the liberation war had emancipated and delivered both the writer and the reader from bondage.

The central proposition being made here is an interesting one where literature plunged an oppressed people into a war of liberation before that literature was stopped, and then the liberation war in turn liberated the writer so that he could write even on politics. Mutsvairo's Feso (1956) allegorically painted a glorious picture of Zimbabwe's past while at the same time painting a grim picture of the existence of Africans under colonialism. The novel also contained a political protest poem O Nehanda Nyakasikana in which the speaker appeals to the guardian spirit of Nehanda to come and rescue her people from slavery. Although the novel was banned and removed from the school syllabus the famous prayer to the spirit of Nehanda, as Ranger (2002:213) points out, was read or recited in the late 1950s and early 1960s at the beginning of the mass nationalist rallies in the townships. The famous prayer to Nehanda fired the Zimbabwean people with aggressive national feelings and inspired many young men and women to take up arms to free their country from colonialism. The armed struggle in turn created the necessary democratic space in which writers could feel free to write about the war that liberated them. Jean-Paul Sartre (1972:384) appears to confirm this symbiotic relationship between literature and liberation war when he states that

\begin{abstract}
... the freedom of writing implies the freedom of the citizen. One does not write for slaves. The art of prose is bound up with the only regime in which prose has meaning, democracy. When one is threatened, the other is too. And it is not enough to defend them with the pen. A day comes when the pen is forced to stop, and the writer must then take up arms. Thus however you might have come to it, whatever the opinion you might have professed, literature throws you into battle.
\end{abstract}

Indeed, Feso (Mutswairo, 1956) and its allegorically political message of resistance "threw the writer into battle" and that battle produced freedom in which the Shona war fiction writers could write about the war of liberation from the point of view of those who were fighting for that freedom. In the absence of political freedom the 
Shona war fiction writer could not hope to publish in colonial Zimbabwe works that depicted the liberation war in the manner he wanted. It was partly the advent of the new political dispensation of independence and freedom that allowed the Shona war fiction writer to glorify the liberation war and present it as a historic and heroic struggle of the oppressed indigenous people against white minority rule. The frequency with which various authors use derogatory and racist terms in their liberation war novels to depict white settlers and their supporters shows the extent to which the writer had been liberated to express himself. If terms used by Patrick Chakaipa in Garandichauya (1963) such as vasina mabvi ("those without knees"), mhuru yomuchena ("white bullock"), and giwa ("big and awesome white man"), could raise concern among white Rhodesians as epitomised by the correspondence between Walter Krog, James Walker and B.B. Fitz-Patrick (Chiwome, 2002:43), Shona war novels with terms like mapuruvheya ("derogatory term for policemen"), mabhunu ("boers"), madzakutsaku ("defected soldiers who fight against the people's wishes") had no chance of getting published. Manuscripts in which fictional characters were given names that expressed the longing for the extermination of white settlers such as Mabhunu-muchapera ("Boers, you will be wiped out"), as well as names that reflected the objectives of the armed struggle like Tichatonga ("We will rule"), could not hope to see the light of the day in colonial Zimbabwe. However, the fact that novels with the kind of content depicted above were published after 1980, is indicative of the existence of a new accommodating environment. This kind of fiction that was written entirely at the service of the armed struggle and which seemed to endorse everything that white Rhodesians found to be particularly revolting belongs to the era of Zimbabwe's independence and freedom. In the first five years of independence alone no less than ten Shona novels about the liberation war were published. Two more came in 1987 and 1990, respectively, and then the zeal died down. There is nothing that happened thereafter that could re-kindle enthusiasm and interest in celebratory liberation war literature again.

However, the question of independence and freedom just discussed cannot be concluded without qualifying the statement freedom to write what one wants. The statement needs to be qualified because there is no intention to give the impression that there was no harassment of artists in Zimbabwe after independence. Fiona Lloyd (1992: 1) notes the arrest of Dambudzo Marechera during the 1984 Zimbabwe International Book Fair for giving an "unauthorised interview" to two Dutch journalists. There is also the case of Cont Mhlan- 
ga of Amakhosi whose play, Workshop negative (1992), ruffled the feathers of the chefs ruling elite, because it interrogated their commitment to socialist ideology. Despite the fact that Workshop negative (Mhlanga, 1992) disturbed the consciences of the ruling elites, the play was not banned and the author was not treated in the same manner as Salman Rushdie in Iran, Ken Saro Wiwa in Nigeria, and Jack Mapanje in Malawi. There was official harassment in Zimbabwe, but it was subtle. For example, when Amakhosi were invited to perform Workshop negative (Mhlanga, 1992) in the region and when later on they were invited by the Spanish government to perform the play at the World Expo with all the expenses paid for, the Zimbabwe Ministry of Culture did not issue the letters to sanction the trips. In fact, the application letter for permission to undertake the trip sponsored by the Spanish government went missing in the Culture Ministry. Amakhosi became a victim of what Justice MacNally once memorably termed "the tyranny of inefficiency" (Lloyd, 1992:2). Yet, despite official discomfort with the play, Workshop negative (Mhlanga, 1992) went on to be published in Zimbabwe in 1992. This shows that although at that time there was a bit of official harassment it never really harmed anyone. It must be remembered, as Henry Louis Gates, Jr. (1990:137) once pointed out in his comments about the plight of Salman Rushdie and Wole Soyinka, that elsewhere "from Chile to Czechoslovakia, men and women languish in prison for a dissidence not of deeds but of words". This is the context in which it has been argued that in Zimbabwe there was freedom to write.

If in the 1990s therefore, Cont Mhlanga's play that was deemed to be ideologically unsound, was published and has remained unbanned and relevant to this day then Shona liberation war fiction could be published without any hitches. After all, unlike Workshop negative Shona liberation war novels were "ideologically correct" since they tended to endorse the official Zimbabwe African National Union (Patriotic Front) (ZANU (PF)) version of the war of liberation. The fate of Workshop negative has been used here as a yardstick to measure the degree of artistic freedom in Zimbabwe during the first decade or so of its independence. Writers were now free to write about Zimbabwe's liberation war and make black guerrillas the heroes of their fiction, a thing they had no freedom to do during the colonial era.

However, while independence and freedom created a favourable political climate in which writers could write about the positive aspects of the war, Shona war fiction writers did not quite have the 
independence and freedom to write about the negative aspects as well. Writers now had the freedom to write about the guerrilla war, but they understood that their freedom went up to a certain point. They did not have the independence and freedom to expose the ugly side of the liberation war too. By their own admission (obtained in interviews with the researcher) writers focused on the positives only. They wrote what they believed readers and those in authority wanted to hear. This accounts for the publication of panegyrics in praise of the war and the nationalist guerrillas.

The scenario that was there early at independence, was in a way, similar to the scenario that was there in colonial Zimbabwe, and both scenarios produced identical results in terms of the quality of literature published. In colonial Zimbabwe writers were ruled by fear. As noted above they feared that if they wrote sensitive issues the Rhodesia Literature Bureau under Walter Krog would reject their manuscripts, and they also feared the police and the law. This resulted in "internalised censorship [which] arises from the existence of many censorship laws [and] inhibits free creativity" (Chiwome, 2002:48). Just as much as in colonial Zimbabwe writers were not free to write sensitive issues because conditions of self-censorship were ever present so too was the situation at independence. Writers at independence practiced a form of self-censorship because conditions that prevailed induced a kind of fear into their hearts. Because they were writing at a time when the nation was in a euphoric and celebratory mood they feared that if they wrote negative things about the war and the guerrillas they would be viewed as retrogressive and anti-revolutionary. It is for this reason that those writers of Shona war fiction wrote narratives that glorified the war and the guerrillas and turned a blind eye to the ugly facts of that war. They feared to be viewed as enemies of the revolution.

This fear was real. This kind of fiction that glorified the war and tended to agree with the ZANU (PF) official version of the war was a form of "internalised fear [that] was sometimes justified as responsible writing" (Chiwome, 2002:48). It was justified as responsible writing because it romanticised the war and totally refused to commit itself and expose the ugly facts of the war, which suited the ruling elites well. It was internalised fear, because whether writers knew it or not they were afraid to write anything that did not agree with the dominant ideology of the ruling class. Writers were exercising caution and self-censorship, because, if direct censorship was rarely used, there was enough of it in the postindependence atmosphere to encourage active self-restraint (Kaarsholm, 2005:4). They now 
had the freedom to tell the story of the liberation war, but they did not have total freedom to give a balanced view of it.

\section{Euphoria and celebration}

Most of the Shona war novels were written and published during the first few years of independence when the Zimbabwean nation was still steeped in the mood of euphoria and celebration. The Shona war novels are therefore part and parcel of that euphoric and celebratory mood. A war that had claimed so many lives had ended and those who survived had a reason to celebrate life. The war that had been fought to remove oppression and racism had brought political independence. The freedom fighters that had promised so much during the war were now in power and people were full of expectations that they would now deliver. Everywhere in the cities, provinces and districts in the countryside people were celebrating.

The euphoria and celebratory mood that gripped the nation was reflected in the songs that were popular at that time. For the first time liberation war songs and other revolutionary songs were aired on national radio and television. They were sung in pubs, on public transport, at rallies and everywhere else. The whole environment resonated with songs that celebrated the armed struggle, independence and freedom. These songs became popular in the early 1980s because of the way they captured and celebrated the happy mood of independence (Vambe, 2002:79). One song sung by the Harare Mambo Band and which was given regular slots on national radio and television welcomed the guerrilla fighters back home, saying:

Mauya, mauya komuredhi

Zvamauya hamuchadzokeri.

Mauya, mauya komuredhi

Zvamauya tongai Zimbabwe.

Welcome, welcome comrade

Now that you have come, you have come for good.

Welcome, welcome comrade

Now that you have come, rule Zimbabwe.

This was an emotional welcome extended to the freedom fighters. The song is a seal of approval to the returned guerrillas. It gives them the unqualified mandate to rule Zimbabwe. Equally, as Pongweni (1982:188) points out, the song VaMugabe Votonga by the Green Arrows celebrates the landslide victory of ZANU (PF) in the hotly contested elections of 1980. 
The brief discussion on songs has been included here just to show that Zimbabweans were indeed celebrating. It is in this situation of abandoned celebration that the Shona novel about the liberation war was born. Everywhere people were singing songs of triumph and self-congratulation. The writer of Shona war fiction wrote his works in an environment that was alive with great happiness, elation and excitement. The songs that were sung made the noises of celebration and euphoria even more audible and the writer could not afford to contribute the voice of dissent and discord. Whether it was by choice or lack of it, the writer marched in harmony with the celebrating nation. Shona war fiction was therefore celebrationist, because it was made at a time of celebration and euphoria. This is the context in which it has been argued that Shona war fiction is an art that tells the story of its own time. It tells the story of a nation in celebration.

The Shona war fiction writers' perspectives on the Second War of Liberation were therefore shaped by the prevailing situation in the country after independence. Because the nation was euphoric and in a mood of celebration the Shona war novel was turned into another arena for celebrating both military and electoral victories. The writer had presumably supported the liberation armies during the armed struggle. To stop supporting the fruits of that struggle now would not make sense. The writer, therefore, joined the rest of the nation to celebrate the victory and the fruits of that armed struggle. This explains why most writers portray the liberation war in very simplistic terms, often focusing on its causes. Instances in which all guerrilla fighters are also wiped out by Rhodesian forces in a battle are unknown or very rare. To portray guerrilla fighters in that light would be regarded as retrogressive. This means that the writer did "not first accept to liberate himself from certain inhibiting angles of vision" (Ngugi wa Thiong'o, 1983:58). His vision of the war of liberation was blurred by the mood of celebration that he was steeped in.

The reality of what happens in a real war situation is that people die on both sides. This is the reality that the Shona war novel fails to portray, because it is part of the independence celebrations. Readers immediately see the relevance of the question that Ngugi wa Thiong'o (1983:58) asks when he wonders whether the artist has equipped himself with a worldview which enables him to see as much of the world as it is possible for him to see and make us see. The authors are not equipped to do this and that is why they are not objective at all in their reporting. Wayne Booth (1972:566) defines objectivity in an author as "an attitude of neutrality towards all va- 
lues, an attempt at disinterested reporting of all things good and evil". An attitude of neutrality towards all values implies being critical. However, Shona war fiction is not critical, because, as Chiweshe (2004:E2) points out, "any literature born out of a celebratory period is never critical". Shona liberation war fiction simplifies history to the level of rendering it very superficial. Those who did not experience the liberation war in Zimbabwe would read this Shona war fiction and think that the war was a lot of fun. If one considers that when at 7 pm on 26 December 1979, Rex Nhongo and 41 ZANLA commanders flew into Salisbury in a Chartered Air Botswana Viscount many thousands of delirious supporters jammed the airport oblivious of tear gas and police dogs (Martin \& Johnson, 1981:320) one understands why Shona war fiction portrays the liberation war as if it was a picnic or an entertaining game. The authors may not have been physically present at the airport on that day, but the euphoria and mood of celebration were quite infectious. It is not surprising therefore that instead of being critical Shona war fiction is one-sidedly sympathetic towards the guerrilla army. The fiction portrays guerrillas that win in nearly all situations, guerrillas that do not get killed even where it is obvious that they should, and guerrillas that appear from nowhere and dissolve into nothingness. In short, the guerrilla fighters are portrayed as super humans who belong to the supernatural world. In fact, the myth of a superhuman guerrilla finds a great deal of direct expression in these Shona war stories.

Another characteristic that shows that the writer of Shona War fiction is euphoric and celebrating victory and independence is the way he seems to endorse the use of violence. The writer shows this by using the device of celebrating the destruction of life and property. He seems to enjoy inflicting pain on his fictional characters and killing them. Perhaps Rouse (cited in Swift, 1951:11) is therefore correct in asserting that

Man is the most predatory and aggressive of animals - with the possible exception of great cats, tiger, and panther. Most animals kill for food or self-protection, for survival, man will kill for pleasure or for fun.

There is also a new source of triumph that grips the Zimbabwean society in the aftermath of the war that makes the author to trivialise war and make it look like a joke. Makata's Gona ReChimurenga, perhaps the first Shona novel about the war to be published in 1982, captures that new sense of triumph that makes one to celebrate death and destruction. He depicts the war as if it was an enjoyable experience. Makata describes a fierce encounter between the gue- 
rrillas and the Rhodesian forces in a melodramatic fashion. For while guns are exploding and people are dying, Mabhunu Muchapera is portrayed as thoroughly enjoying himself. He laughs, exchanges glances with fellow comrades and smiles while killing, and he tells the reader that Chokwadi neimwe nguva hondo inodadisa, inonakidza (Makata, 1982:31). ("Honestly, at times war makes you proud; it's a sweet experience".)

While Makata's Gona ReChimurenga (1982) is probably the first Shona novel about the liberation war to be published, and therefore captured the mood of celebration at its earliest and at its wildest, Raymond Choto's Vavariro (1990) comes at the end of the first decade of independence and demonstrates that the euphoria and mood of celebration still prevailed. Although Choto shows that some disillusionment was creeping in, still the best part of the population retained positive images of the years of the armed struggle. From the 1990s' perspective Choto continues to celebrate victories won more than a decade earlier. His diction and tone show that he writes for a nation still in celebration. He demonstrates this by the manner in which he depicts the sounds of guns fired by guerrillas. The author says: Tumirai Akabva aridza pfuti yake sango rose ndokubva radavira (Choto, 1990:50), ("He fired his gun and the whole veldt answered back"); Tumirai akatepfenyura bazooka gomo rose ndokubva radavira (Choto, 1990:50), ("Tumirai fired his bazooka and there were echoes from the mountain"); Akatumirazve rimwe bara ndokubva gomo rose radavira (Choto, 1990:81), ("He released another bullet and the whole mountain responded"). There is something special about the way guerrillas in Choto's novel do their thing; something that makes war such a simple matter. Their guns always reverberate in a manner that makes war sound like sweet music. However, those who were physically fighting in that war know that each echo from the mountain brought with it news of death.

Perhaps the reason why these authors of Shona liberation war fiction tended "to romanticize and deodorise the liberation struggle" (Chiweshe, 2004:E2) is that they did not physically take part in the actual fighting itself. They participated in the war in various other capacities other than the capacity of armed guerrilla fighters. Many of them were supporting the war from a reasonable distance as teachers, students or ordinary civilians. That is probably why they are not able to examine the emotional and psychological impact of prolonged exposure to war, suffering and death. Those who were involved in the armed struggle itself, like Alexander Kanengoni (1997), Isheunesu Valentine Mazorodze and Freedom Nyamubaya, 
capture the war more realistically in Echoing silences (Kanengoni, 1997), Silent journey from the East (Mazorodze, 1989), and On the road again (Nyamubaya, 1986), respectively. These three succeed to show that "The war did not produce angels out of all its participants" (Mazorodze, 1989:148). Shona war novelists chose to ignore its unpleasant aspects. They thought they were helping the nation to celebrate and yet they were denying the entire nation vital information about the war.

\section{Dominant ideology of post-war era}

Literature, any literature, has the potential to reflect the dominant mood of its epoch. Shona war fiction is no exception. Shona war fiction writers' perspectives on the liberation war were shaped by the dominant ideology of postcolonial Zimbabwe. This fiction shows the harmonious relationships that exist between literature and ideology. As Ngara (1985:21) says: "Literature is socially conditioned and makes us see the ideology from which it is born." Shona war fiction tells the truth of its time in the sense that it makes us see the dominant ideology from which it is born, which is the ideology of postindependence Zimbabwe.

The discussion of this aspect will proceed by adopting Ngara's $(1985: 20)$ position of defining ideology as "referring to the dominant ideas of an epoch or class ...." It will also be guided by Marx and Engels' thinking that "the ideas of the ruling class are in every epoch the prevailing ideas" (Ngara, 1985:21). This therefore means that the dominant ideas of the postcolonial epoch in Zimbabwe are considered to be the ideas of the ruling class.

Shona war fiction in content and form seems to be an expression of the thinking of the original ZANU (PF). The ideas projected by the novels endorse the dominant ideology that places Robert Gabriel Mugabe at the centre of the new political dispensation. Robert Mugabe is seen as the one who will replace lan Smith and a socialist mode of production the one to replace the capitalist one. Shona war fiction writers had the advantage of hindsight in that they wrote at a time that a new black government was in power. Robert Gabriel Mugabe was already the Prime Minister of independent Zimbabwe. For these writers it was a matter of confirming the truth that was already there. While ZANU and the Zimbabwe African National Liberation Army (ZANLA) were fighting the war mainly from the east, Zimbabwe African People's Union (ZAPU) and its Zimbabwe People's Revolutionary Army (ZIPRA) were also fighting from the western side. However, all Shona war novels make no mention 
of ZAPU and its leadership. This silence on any other party or leader agrees with the ideology of one party state. One can go so far as to argue that the Shona liberation war novel is actually in harmony with the Zimbabwe African National Liberation Army choir's song that tells the nation that only ZANU (PF) waged the armed struggle. In fact the song takes the form of a question and answer in which the leader asks the question Chimurenga chakarwiwa naniko? ("Who waged the armed struggle?") and the rest of the choir members respond by saying NeZANU (PF) ("By ZANU (PF)"). ZAPU and its Zimbabwe Peoples' Revolutionary Army are of no consequence in this equation. This is in line with the ruling party's ideology of oneparty state.

The Shona war novel also seems to endorse the philosophy of socialism that the new black government expounded. The dominant socialist ideology that ZANU (PF) brought with it from the liberation struggle and which was meant to be its guiding principle in the first decade of independence affected the contents of Shona war fiction and determined its scope and direction. One may go so far as to argue that the writers used Shona war fiction as part of a wider programme of political acceptance of the new dispensation and endorsement of the liberation war and its conduct. The socialist ideology is well articulated in Zvaida Kushinga (1985) by Josiah, who advocates that Tinoda kurwisana noumbimbindoga kuti vanhu vakwanise kugovana upfumi hwenyika yavo (Makari, 1985:81). ("We want to fight against individualism so that people can share the wealth of their country.")

This perspective is shaped by the dominant ideology of the epoch that influences writers to try and conscientise the masses and rally them behind the political, social and economic programmes of one of the parties that spearheaded the armed struggle against colonialism. These programmes are centred on the ideals of one party state, egalitarianism, unity and comradeship. The circumstances prevailing in the post-war period were different from those of the 1970s. The nation was now facing new challenges and it could only prosper if its people shared common vision, and that vision was guided by the philosophy of socialism.

It has been argued and demonstrated that post-war euphoria, mood of independence as well as the dominant ideology of the epoch immensely influenced Shona writers' perspectives on the armed struggle in Zimbabwe. The Shona war novel reflects the mood, the spirit and the thinking of the period in which it was born. This is the context in which it has been pointed out that Shona war fiction tells 
the truth of its own time. Lawrence (1972:123) puts it aptly when he says that "Art-speech is the only truth. An artist is usually a damned liar, but his art, if it be art, will tell the truth of his day and that is all that matters." Ngugi wa Thiongo (1981:72) adds more weight to this argument by postulating that "literature has often given us more insights into the moving spirit of an era than all the historical and political documents treating the same moments in a society's development". Every writer is a product of his historical epoch and Pearce $(1974: 361)$ points out that

[w]e must, therefore, consider the literary work as it is a kind of statement which can never be dissociated from either the time in which it was made or the time in which it was known.

Shona war fiction belongs to the postindependence era in Zimbabwe and it cannot be dissociated from the celebration, the euphoria and the dominant thinking of that time. Literature in Elizabethan England was placed at the service of religion, because the Catholic Church provided the dominant religion, and William Shakespeare was a child of his time who was influenced by the dominant ideology of his age which believed in the doctrine of the Devine Right of Kings (Ngara, 1985:22). The Shona war fiction writer is also a child of his own time who was influenced by the dominant ideology of postindependence Zimbabwe. So, Chiweshe (2004:E2) is correct in saying the following:

Just like how everyone supported the nationalist ideology in their respective fields, so did the writers use the pen in support of this popular ideology. It brought them satisfaction and selfgratification to know that they are in support of the fruits of independence.

This explains why writers distorted and simplified history. They were agreeing with the dominant ideology of the time they were writing in. To agree with the dominant ideology of their time meant that they had to practice self-censorship so as to avoid writing anything that went against that dominant ideology.

\section{Literary competitions}

Competitions, whether in class, business, farming, beauty, sport or any other aspect of human endeavour, will always encourage people to bring out their best and to do more. Sometimes competition encourages people to do things they were not thinking of doing in the hope of winning and getting a reward or recognition. 
For many years competitions have been a feature of Zimbabwean literary life. Organisations like the Literature Bureau, the National Theatre Organization, Zimbabwe Book Publishers' Association and the National Arts Council have at various stages organised literary competitions. A sizeable number of plays, novels and poetry books have been subjected to one kind of literary competition or another. Among the novels and short stories that were published after the manuscripts were entered for a literary competition organised by the Literature Bureau are those works that deal with the theme of The Second War of Liberation in Zimbabwe. The Literature Bureau had its own budget to fund the literary competitions and winners got monetary rewards, in addition to being published.

During the first few years of Zimbabwe's independence the Literature Bureau launched literary competitions in which writers were required to write on the theme of Zimbabwe's liberation war. What this means is that the Literature Bureau made a direct and deliberate intervention into the literary life of the nation in order to influence its direction and growth. The Literature Bureau launched the competitions specifically for those who were interested in writing about the armed struggle. Or conversely, it was the Literature Bureau that was interested in the theme of liberation war since, according to Bisset Chitsike (2007) (in an interview with the researcher), there was a vacuum in that area. Chitsike, who joined the Bureau in 1969 and rose through the ranks to become the Chief Publications Officer in 1986, said that the response was overwhelming and manuscripts came in large numbers. Moyo also confirmed in an interview with the researcher that it was the introduction of literary competitions that created the stampede that resulted in the concentration of published war novels and short stories in the years between 1982 and 1985. In fact, according to Moyo, these were the years when the Literature Bureau invited manuscripts on "dictated themes". Hondo yeChimurenga (1984), a collection of nineteen short stories about the liberation war, is an example of a product of a literary competition organised by the Literature Bureau.

Elsewhere in this article it has been argued that literature that is born at a time of celebration is hardly critical. Equally, literature that is born out of a competition may also be affected by the demands of competition, either positively or negatively. In the case of the Shona war stories the competitions were launched in a moment of euphoria and celebration. The standard practice in most competitions is that a panel of judges, whose decision is final, assesses the manuscripts. Hence, there is always the likelihood that the competitor, who is 
motivated largely by the desire to win, will make every effort to court the judges. Robert Collier (2009) has a quote that says that in a competition "You must set in operation a process of competition, from which one must emerge a victor and the other set be defeated." This is precisely what some war fiction writers who joined the competitions did. Chitsike (in an interview with the researcher) charged that "some wrote to impress us, because they wanted to win the competition". Chitsike used the term impress to imply that the writers made extra effort to glorify the armed struggle in order to please the judges and influence the verdict in their favour. He explained that people were afraid to write anything that was good, despite appeals on radio and at workshops for people to write balanced stories. In fact, if the majority of Shona war stories that were published are a measure of the effectiveness of this appeal then the appeal was a total failure.

When Chitsike talks of people fearing to write "anything that was good" there is a body of Marxist thinking there. He implies that there is no realism, which Engels (quoted in Williams, 1972:583) defines as "typical characters in typical situation". The point being made here is that the competitors must have reasoned that judges were part of that euphoric and celebrating population, so if one hoped to win the competition the best one could do was to celebrate with the judges themselves. Vitalis Nyawaranda (2007) (in an interview with the researcher) confirms that thinking when he says:

It is possible to think that judges wanted a certain position. Anything that was anti-guerrillas would possibly not win at that time. We thought that the judges wanted the kind of stories that we were sending them.

This is an admission on the part of writers that they rationed information, releasing only that which they thought the judges wanted to be told. It shows that writers were censoring themselves.

Winning a competition carries with it an additional incentive in the form of a prize, be it money or commendation or something else. In the case of literary competitions organised by the Literature Bureau the prizes were in the form of money, and that is precisely what Nyawaranda (1985) targeted. Nyawaranda admitted in the interview that money was his prime motive for joining these competitions:

My prime motive was money. I was not even targeting royalties. That would come later. I was targeting prize money for the first position which was $\$ 600$. $\$ 600$ was a lot of money at that time, and that is what I wanted. The manuscripts that came first and 
second would then get published. Those that got third prize would be revised accordingly and get published later.

Nyawaranda (1985) did not get first prize for Mutunhu Une Mago (1985) although that was his major intention when he joined the competition. However, he got first prize for his short story Tamba Wakachenjera and Moyo won second prize for the short story, Ndaponda Gandanga, both of which appear in Hondo YeChimurenga (Literature Bureau, 1984).

Moreover, the winning manuscripts were sent to publishing houses like Mambo Press, College Press, Longman and Zimbabwe Publishing House where they were published in Association with the Literature Bureau. Once published the author was guaranteed to get some royalties from the sales. Government guaranteed to buy a certain number of copies of each published book to put in school and public libraries, and other copies would hopefully be bought by the reading public and by the schools themselves.

This commoditisation of art was bound to affect the writer's perception of the liberation war. The writers tended to portray the war in a manner that they thought would please the consumers of the literature. This accounts for the idealisation of the war as opposed to realism. Writers must have imagined too that if they endorsed the official ZANU (PF) version of the war their published works stood a good chance of being prescribed as set books for schools and hence gain a ready market that would guarantee them good money. This confirms Lloyd's (1992:3) assertion that "if you want funds and official approval it's still a good idea to avoid rocking political boats".

If authors wrote negative things about the guerrillas there would be no ready market for their novels. So they censored themselves, in this case for financial gain. The result was that their art was underdeveloped. Charles Makari (2007) (in an interview with the researcher) confirmed this when he admitted:

I self censored my book. For instance, many girls were raped during the war. But I was targeting school going age in my book. I wanted to write things that were readable. I wanted to write things that were forward-looking and positive. The negative will have its time in the future.

This approach resulted in the publication of fiction that supported the popular version of the war that publishers would sell fast to the people while they were still drunk with euphoria and celebration. However, as Chiwome (2002:73) says, best sellers are not the best 
books in developmental terms. They aim at mindless entertainment, which is what most of the Shona war novels and short stories turned out to be.

\section{Conclusion}

In this article it has been shown that several war stories were published soon after independence and that this was largely due to political independence and freedom that created reasonable democratic space in which writers could write about the liberation war with minimum restrictions. However, the Shona liberation war literature that emerged was unrealistic and one-sided. At one level there is this lack of realism in the manner in which writers portray the liberation war of the 1970s and the guerrillas who were involved in it. However, at another level that failure to portray Zimbabwe's liberation war realistically is itself a reflection of the influence of circumstances that prevailed in the post-war era when war fiction was written. It is in this sense that it has been argued that Shona war fiction is an art that "tells the truth" of its time. The truth that is meant here is not the truth of what happened during the war. It is the truth of what was happening during the first decade of independence, which is the time that Shona war fiction was written. In other words, all Shona war fiction writers distort history of the liberation war but that fact of distorting history reveals a certain fundamental truth about the early years of Zimbabwe's independence. That fundamental truth is that Zimbabwe was in a moment of triumph, celebration, and euphoria, and that is why Shona war fiction is celebrationist. The fiction also tells a true story of a postindependence era in which direct censorship was not used, yet it existed in the minds of the writers, such that they became cautious and therefore exercised self-censorship. So while external factors played a role in influencing writers to distort reality internal fear on the writers' part also played a major role.

\section{List of references}

BOOTH, W. 1972. "Objectivity" in fiction. (In Lodge, D., ed. 20th century literary criticism. London: Longman. p. 565-579.)

CHAKAIPA, P. 1963. Garandichauya. Salisbury: Longman.

CHENNELS, A. 1995. Rhodesian discourse: Rhodesian novels and the Zimbabwean liberation war. (In Bhebe, N. \& Ranger, T., eds. Society in Zimbabwe's liberation war. Vol. 2. Harare: University of Zimbabwe Publications. p. 102-129.)

CHITSIKE, B. 2007. Oral report to author on 19 Jul., Harare.

CHIWESHE, L. 2004. Local writers romanticize the war ... except Kanengoni, Nyamubaya. Sunday mail: E2, 10 Oct. 
CHIWOME, E.M. 2002. A social history of the Shona novel. Gweru: Mambo Press.

CHOTO, R. 1990. Vavariro. Harare: Baobab.

COLLIER, R. 2009. Robert Collier quotes. http://www.cybernation.com Date of access: 15 Jul. 2009.

EARLY, R. 1977. A time of madness. Salisbury: Graham.

GATES, H.L., Jr 1990. Censorship and justice: on Rushdie and Soyinka. Research in African literatures, 21(1):137-139.

HARTMANN, M. 1973. Game for vultures. London: Heinemann.

IZEVBAYE, D.S. 1990. Shifting bases: the present practice of African criticism. Research in African literature, 21(1):127-136.

KAARSHOLM, P. 2005. Coming to terms with violence: literature and the development of a public sphere in Zimbabwe. (In Muponde, R. \& Primorac, R., eds. Versions of Zimbabwe: new approaches to literature and culture. Harare: Weaver Press. p. 3-23.)

KANENGONI, A. 1997. Echoing silences. Harare: Baobab.

LAWRENCE, D.H. 1972. The spirit of place. (In Lodge, D., ed. 20th century literary criticism. London: Longman. p. 122-127.)

LITERATURE BUREAU. 1984. Hondo yeChimurenga. Gweru: Mambo Press.

LLOYD, F. 1992. Harassment or self censorship? (The dilemma of the Zimbabwean writer.) Paper presented at the Zimbabwe International Bookfair Writer's Workshop, Harare, 2 Aug.

MAKARI, C. 1985. Zvaida kushinga. Gweru: Mambo Press.

MAKARI, C. 2007. Oral report to author on 20 Jul., Harare.

MAKATA, M. 1982. Gona reChimurenga. Gweru: Mambo Press.

MARTIN, D. \& JOHNSON, P. 1981. The struggle for Zimbabwe. Harare: Zimbabwe Publishing House.

MAZORODZE, I.V. 1989. Silent journey from the East. Harare: Zimbabwe Publishing House.

MHLANGA, C. 1992. Workshop negative. Harare: College Press.

MOYO, A.C. 2007. Oral report to author on 19 Jul., Harare.

MUTSWAIRO, S. 1956. Feso. Harare: Longman.

NGARA, E. 1985. Art and ideology in the African novel. London: Heinemann.

NGUGI wa THIONG'O. 1981. Writers in politics. London: Heinemann.

NGUGI wa THIONG'O. 1983. Barrel of a pen: resistance to repression in colonial Kenya. Trenton: Africa World Press.

NYAMUBAYA, F. 1986. On the road again. Harare: Zimbabwe Publishing House.

NYAWARANDA, V. 1985. Mutunhu une mago. Harare: Longman.

NYAWARANDA, V. 2007. Oral report to author on 20 Jul., Harare.

PEARCE, R.H. 1974. Historicism once more. (In Handy, W.J. \& Westbrook, M., eds. Twentieth century criticism: the major statements. New York: The Free Press. p. 352-365.)

PONGWENI, A.J.C. 1982. Songs that won the liberation war. Harare: College Press.

RANGER, T. 2002. History has a ceiling: the pressures of the past in The stone virgins. (In Muponde, R. \& Taruvinga, M., eds. Sign and taboo: perspectives on the poetic fiction of Yvonne Vera. Harare: Weaver Press. p. 203216.)

SARTRE, J-P. 1972. Why write? (In Lodge, D., ed. 20th century literary criticism. London: Longman. p. 370-385.) 
STIFF, P. 1973. The rain goddess. Salisbury: Jacaranda.

SWIFT, J. 1951. Gulliver's travels. London: Pan.

VAMBE, M.T. 2002. Popular songs and social realities in postindependence Zimbabwe. (In Jones, E.D. \& Jones, M., eds. South and Southern African literature, 23. Oxford: Currey. p. 79-90.)

WILLIAMS, R. 1972. Realism and the contemporary novel. (In Lodge, D., ed. 20th century literary criticism. London: Longman. p. 580-591.)

ZANZA, E.H. 1971. Hunde yorufu. Gweru: Mambo Press.

\section{Key concepts:}

artistic freedom

euphoria and celebration

liberation war novels

self-censorship

Shona war fiction

Kernbegrippe:

artistieke vryheid

euforie en feesviering

selfsensuur

Shona-oorlogsfiksie

vryheidstrydroman 